\title{
Biomass production, carbon sequestration and economics of on-farm poplar plantations in Punjab, India
}

\author{
S. K. Chauhan ${ }^{1}$, R. Sharma ${ }^{1}$, B. Singh ${ }^{2}$ and S. C. Sharma ${ }^{3}$ \\ ${ }^{1}$ Department of Forestry and Natural Resources, ${ }^{2}$ Krishi Vigyan Kendra Sri Muktsar Sahib , Regional Research \\ Station for Kandi Area, Ballowal Saunkhri, Punjab Agricultural University, Ludhiana - 141004 (Punjab), INDIA \\ Corresponding author. E-mail: chauhanpau@pau.edu
}

Received: December 9, 2014; Revised received: .March 19, 2015; Accepted: 2 June, 2015

\begin{abstract}
Six years poplar plantations were assessed for productivity, carbon storage and economics in comparison to sole cropping. Wheat grain yield was significantly higher in control plots $(4.55 \mathrm{t} / \mathrm{ha})$ than boundary plantation ( 3.28 $\mathrm{t} / \mathrm{ha}$ ) and block plantation (2.03 t/ha). Similar trend was recorded for straw yield (6.61 t/ha in control plots, $4.83 \mathrm{t} / \mathrm{ha}$ in boundary plantation and $3.5 \mathrm{t} / \mathrm{ha}$ in block plantation. The boundary plantation produced higher $\mathrm{DBH}(24.23 \mathrm{~cm})$ than the block plantation $(19.71 \mathrm{~cm})$. The crown spread itself followed the same trend but both the planting methods had almost similar plant height. However, the total tree biomass was higher with block plantation (96.31 t/ha) than boundary plantation ( $30.14 \mathrm{t} / \mathrm{ha}$ ) but per tree biomass was more in boundary plantation than block plantation. The total carbon storage was higher in block planting method (55.43 t/ha) than in boundary plantation (32.70 t/ha) and lowest total carbon storage in sole cropping system (31.20 t/ha). The heat from biomass combustion and carbon storage from coal substituted of timber was also higher in the block plantation $(18.67 \mathrm{t} \mathrm{C} / \mathrm{ha})$ as compared with boundary plantation (4.43t C/ha). Agro forestry systems likely had a greater capacity to sequester $\mathrm{C}$ in the longterm than the annual cropping systems because of their diverse configurations. The economic benefits were also higher in block plantation than boundary and sole cropping of rice-wheat $(B: C$ ratio of $3.30,1.90$ and 1.61 , respectively). Adoption of on-farm poplar plantations will develop new opportunities for enhanced income in addition to employment and environmental amelioration.
\end{abstract}

Keywords: Boundary/block plantation, Carbon sequestration, Energy, On-farm poplar

\section{INTRODUCTION}

Rice (Oryza sativa L.) and wheat (Triticum aestivum L.) are traditionally dominant crops, cropping system is very important for food security in India and adjoining countries. This rotation of irrigated agro-ecosystem in north-western states of India has not remained sustainable i.e., resulted in lowering ground water table, nutrient and organic carbon imbalance, etc. It has also put a stigma on the sustainability of future agriculture and ecological balance, thus, necessitating the diversification in this crop rotation and more specifically the rice cultivation (Regmi et al., 2002; Prasad and Nagrajan, 2004; Senapati et al., 2010). .

Tree provides an assurance to the farmers against any uncertainty on agricultural production but the intensive agriculture on irrigated agro-ecosystem has resulted in removal of trees from agricultural landscape. Trees improve soil productivity through ecological and physico-chemical changes depending upon pumping of nutrients from lower horizon to top layer, the quantity and quality of litter reaching the soil surface, the rate of litter decomposition, and nutrient release. In addition, introduction of trees in agricultural farms is a useful tool to lock up the carbon in tree components and increase the soil carbon status because the presence of trees affect carbon dynamics directly or indirectly (Singh, 2005; Khan and Chaturvedi, 2007; Takimoto et al., 2009; Dhillon et al., 2011; Rytter, 2012; Saha and Jha, 2012). Various interacting factors through which a tree influences carbon stock in the soil under agro forestry are addition of litter, maintenance of higher soil moisture content, reduced surface soil temperature, proliferated root system, enhanced biological activities and decreased risk of soil erosion (Singh and Rathod, 2002; Sanchez et al., 2003; Schultz et al., 2004; Gupta et al., 2006; Singh and Sharma, 2007; Koul and Panwar, 2008; Yadav et al., 2011; Pinho et al., 2012; Ramesh et al., 2013). Agro forestry systems likely have a greater capacity to sequester $\mathrm{C}$ in the long-term than the annual cropping systems (Nair et al., 2009, 2010; Chauhan et al., 2010a,b, 2011, 2012; Benbi et al., 2012; Jose and Bardhan, 2012).

Owing to poplar's fast growth, deciduous nature, marketing acceptability and successful intercropping, agro forestry system has emerged one of the viable alternate land use system to prevent further degradation and obtain biological production on sustainable basis in the irrigated agro-ecosystem (Newman, 1997; Chandra, 2011; Wani and Malik, 2014). Depending upon the 
land resources, poplar has been grown by farmers as boundary as well as block plantation, which improves the physico-chemical properties of soil through addition of organic matter in the soil (Singh and Sharma, 2007; Coleman et al., 2004; Gera et al., 2006; Takimoto et al., 2009) and provides alternate sources of income/employment to the rural poor. Agro forestry practices can also give the landowner larger net gains of carbon per unit land area than other traditional crop rotations.

The carbon sequestration in soils at variable depths due to biomass turnover in agro forestry is also more than conventional agricultural rotations (Paul et al., 2002; Sauer et al., 2007; Nair et al., 2009; Schoeneberger, 2009; Chauhan et al., 2010). However, poplar being sensitive to water logging is not suitable under rice based cropping system, but boundary plantation of poplar is an option to continue traditional rotation of rice-wheat for the farmers who seem reluctant to leave the rotation because of assured market for both the crops. Also, the small and marginal farmers cannot afford to raise block plantation at the cost of agricultural crop and a large scale area is already under poplar boundary plantation in Punjab and adjoining states (Sharma et al., 2001; Singh, 2005; Gera et al., 2011; Rizvi et al., 2011; Kanime et al., 2013). Since less than 50 per cent of total timber is locked for longer time and the remaining biomass is used as fuel which also meets energy requirements and replaces fossil fuel. Therefore, an attempt has been made to compare the yield, carbon sequestration (not in timber but as fuel substitute as well) and economic potential of poplar block and boundary plantation with traditional crop rotation, which are the driving factors for attracting the farmers towards the adoption of tree farming system to diversify traditional rice-wheat cropping system.

\section{MATERIALS AND METHODS}

A field experiment was conducted at Balachaur, SBS Nagar (Punjab). The experimental site is located at $31^{\circ}$ $6{ }^{\prime} 5^{\prime} \mathrm{N}$ and $76^{\circ} 23^{\prime} 26^{\prime} \mathrm{E}$ at $355 \mathrm{~m}$ above the mean sea level. The site is characterized by sub-tropical climate with hot and dry summers from April to June, hot and humid from July to September and cold winter from December to January with average annual rainfall of approx $1000 \mathrm{~mm}$. The soil was loam $(0-15 \mathrm{~cm})$, sandy loam $(15-30 \mathrm{~cm})$ and loamy sand $(30-60 \mathrm{~cm})$ in texture. The soil was found slightly alkaline in reaction (7.49) and low in organic carbon $(0.31 \%)$, low in alkaline $\mathrm{KMnO}_{4}$-extractable $\mathrm{N}(180 \mathrm{~kg} / \mathrm{ha})$, medium in $0.5 \mathrm{~N} \mathrm{NaHCO}_{3}$-extractable $\mathrm{P}(17.1 \mathrm{~kg} / \mathrm{ha})$ and medium in $\mathrm{NH}_{4} \mathrm{OAc}$-extractable $\mathrm{K}(136.8 \mathrm{~kg} / \mathrm{ha})$.

The rice crop followed wheat in boundary plantation but only wheat in block plantation (due to excessive shade during summer months) was followed in poplar based system. In boundary plantation, single row of plants at $2.5 \mathrm{~m}$ apart all along the field were planted, whereas, in block plantation, the spacing of $4.5 \mathrm{~m} \times 3$ $\mathrm{m}$ was maintained. The Package of practices of Punjab Agricultural University, Ludhiana, India for the cultivation of summer (rice - Pusa 44) and winter crops (wheat - PBW 343) were followed for their cultivation and management. The rice crop was harvested manually in the month of October and wheat crop in the month of April. There was no other special management practices followed for poplar except pruning of the tree from second year onwards of transplantation (during $2^{\text {nd }} / 3^{\text {rd }}$ year one third, $4^{\text {th }} / 5^{\text {th }}$ year half and $6^{\text {th }}$ year $2^{\text {nd }} / 3^{\text {rd }}$ of the tree stem was pruned) and regularly irrigated.

Trees data: Six year old trees were measured for their top height, diameter at breast height (DBH) and crown spread. The total height was measured with Altimeter (m) from ground to top of the trees. The diameter at $1.37 \mathrm{~m}$ above the ground level was taken with the help of digital caliper. Crown spread was measured using meter tape and two poles holding straight touching to the outmost tip of the opposite sides of the tree. The distance between these two poles were recorded with the help of measuring tape. Similarly, it was repeated at perpendicular to measure the other direction.

Grain yield: The grain yields of both the crops were recorded from $1 \mathrm{~m}^{2}$ quadrant from nine spots in each replication. However, in boundary plantation, data were recorded on all the four directions at variable distances ( 2 to $10 \mathrm{~m}$ from poplar tree row) to compute the average values. The average grain yield of quadrant was extrapolated to give yield in $\mathrm{t} / \mathrm{ha}$ by bringing the produce at $14 \%$ grain moisture content. The weight of straw was also computed in t/ha on dry weight basis.

Soil properties: The soil samples were collected at 0 $60 \mathrm{~cm}$ depths and analyzed for carbon by Walkley and Black method. The soil bulk density was measured by the core method (Blake and Hartage, 1986) to express the soil organic carbon ( $\mathrm{t} / \mathrm{ha}$ ) by multiplying the soil organic carbon $(\%)$ with bulk density and volume of $0.15 \mathrm{~m}$ furrow slice per hectare (Gupta et al., 2009).

Carbon sequestration in plants: The randomly collected plant samples (poplar, rice and wheat) were analyzed for $\mathrm{C}$ content. The carbon content in different tree/crop components (above and below ground) was estimated on CHNS analyzer to calculate the carbon storage in each component of poplar (stem, branch, bark, leaves and root) and in rice and wheat crop (straw, grain and root). The total carbon storage was computed by using the carbon values of respective component and multiplying the same with the biomass of each component. Tree biomass (non-destructive) was computed by using the regression equations (based on tree height and DBH) developed in prevailing agro-climatic zone (Sharma et al., 2007).

Timber obtained from the fast growing trees has short life span and less than $50 \%$ of total biomass is used for plywood, paper, etc. Approx $60 \%$ of the biomass is contributed by the stem, which means only $25 \%$ of the 
wood goes to durable products \& rest is used for energy to replace fossil fuels. The weight of biomass fuel equals the total biomass weight minus the long-lived stem wood weight, whereas, the long lived carbon storage in timber was estimated as the multiple of 42.46 per cent of wood, which goes to durable products and carbon biomass in stem wood. The heat value of the remaining biomass (short lived - 57.54\%) which is generally used as fuel equals to total biomass minus long lived stem weight multiplied with the heat released per unit weight of biomass, which is equal to $18 \times 10^{9} \mathrm{~J} / \mathrm{t}$ (Wang and Feng, 1995). Additionally, since biomass is replacing fossil fuel, therefore, carbon saving from coal substitution can be estimated by considering the thermal efficiency of biomass in comparison to fossil fuel $(60 \%)$, heat released by unit weight of coal $\left(25 \times 10^{6} \mathrm{~J} / \mathrm{t}\right)$ and the carbon content of coal (70\%). The carbon sequestered in agro forestry is the sum of long term carbon storage in wood products, the carbon savings due to fossil fuel substitution and soil organic pool.

Statistical analyses: The average data in four replications on growth, biomass, carbon and allocation in poplar/cereal crops and soil were suitably analyzed after following the established procedures on computer. Significant differences among the treatment means (different age plantations) for growth, biomass and carbon storage were tested at $\mathrm{p} \leq 0.05$ using least significant difference values (Panse and Sukhatme, 1978).

\section{RESULTS AND DISCUSSION}

Trees growth and biomass: The trees growth and biomass estimates varied between the two poplar planting patterns (Fig. 1) indicating higher DBH with boundary plantation $(24.23 \mathrm{~cm})$ than the block plantation (19.71). However, both the planting methods had almost similar plant height $(22.12 \mathrm{~m}$ and $22.05 \mathrm{~m}$, respectively). The crown spread itself was slightly more in boundary plantation than block plantation (45.97 and $43.21 \mathrm{~m}^{2}$ ). However, the total biomass production was higher with block planting methods (96.31 t/ha) than the boundary planting method (30.14 t/ha). The total biomass was $213 \%$ more in block plantation with $362 \%$ more trees than boundary plantation. In other words, per tree biomass was more in boundary plantation than block plantation due to more diameter growth in boundary plantation than block plantation. The block plantation tree diameter recorded in present study was lower than reported in earlier studies (Chauhan et al., 2010b) due to higher density of poplar trees in block plantation, which resulted in lower per tree biomass under block plantation. The higher biomass under block plantation than boundary plantation was due to continuous cultivation of inter-space, which supplements fertilizer, irrigation and soil aeration (Rizvi et al., 2011). However, lower per tree biomass in block plantation was due to more number of trees on unit scale, which resulted in lower diameter.

Grain yield and straw yield: The grain yield of wheat crop was maximum under control plots i.e., 4.55t/ha, which was higher than the crop under boundary plantation (3.28 t/ha) and lowest (2.03 t/ha) at block plantation (Fig. 2). Similarly the straw yield of wheat crop was maximum under control plots i.e., 88 per cent more than block and 36.8 per cent more than boundary planted system. During summer season, rice was grown in control and boundary plantation, whereas, no crop was grown in block plantation (poplar does not tolerate stagnating water). The grain yield of rice was higher $(46.97 \%)$ with control $(7.42 \mathrm{t} / \mathrm{ha})$ than in the boundary plantation plot (4.74 t/ha). Similarly, the straw yield of rice was higher in field with no poplar trees $(10.45 \mathrm{t} / \mathrm{ha})$ than in the boundary plantation $(7.11$ $\mathrm{t} / \mathrm{ha}$ ). This reduction was however, variable on different row directions due to more shading affect of southwestern rows than north-east rows but figures presented here are average of the total area.

Carbon storage : The carbon storage in the soil was higher in block planting method $(2.47 \mathrm{t} / \mathrm{ha})$ than the boundary planting method $(0.431 \mathrm{t} / \mathrm{ha})$ and rice-wheat cultivation $(0.247)$. The higher soil organic carbon in agroforestry intervention was recorded under both the plantations systems than sole crop cultivation. However, the rate of soil organic carbon buildup depends upon many factors i.e., amount/quality of biomass input by trees and inter-cultivated crops, soil physical/ chemical/biological properties, climate, period of retention, etc. (Nair et al., 2010). An average soil organic carbon increase from 0.36 in sole crop to 0.66 per cent in Populus deltoides (poplar) based agroforestry soils have also been recorded earlier (Gupta et al., 2009). The soil organic carbon increased with increase in tree age. The poplar trees could sequester higher soil organic carbon in $0-30 \mathrm{~cm}$ profile during the first year of their plantation $(6.07 \mathrm{t} / \mathrm{ha} /$ year $)$ than the subsequent years (1.95-2.63 t/ha/year). The sandy clay soil sequestered higher carbon ( $2.85 \mathrm{t} / \mathrm{ha} /$ year $)$ than in loamy sand (2.32 t/ha/year). However, soil organic carbon (SOC) from agroforestry will revert back once the system is discontinued (Benbi et al., 2012). Therefore, the SOC under agroforestry plantations is temporary in nature.

Variable estimates of carbon storage under poplar based system have been presented due to their planting geometry, density, age, etc. (Chauhan et al., 2012). The poplar tree timber in block planting method stored the higher carbon $(21.99 \mathrm{t} / \mathrm{ha})$ than the boundary planting method (10.4 t/ha) (Fig. 3). Similarly in the branch wood, block planting method stored the higher carbon $(3.08 \mathrm{t} / \mathrm{ha})$ than the boundary planting method $(1.29 \mathrm{t} /$ ha). Whereas, the root, leaves and bark stored the lesser carbon in boundary planting method (2.19 t/ha) followed by higher with block planting method (4.12 t/ ha). The wheat crop in controlled plot stored more carbon $(4.45 \mathrm{t} / \mathrm{ha})$ and followed by boundary plantation method (3.36 t/ha) and lowest with block plantation 
Table 1. Biomass production and carbon sequestration by different components in different agroforestry systems.

\begin{tabular}{|c|c|c|c|c|c|c|c|}
\hline \multicolumn{2}{|c|}{ Treatments* } & $\begin{array}{c}\text { Total } \\
\text { bio- } \\
\text { mass*** } \\
(\mathbf{t} / \mathbf{h a})\end{array}$ & $\begin{array}{l}\text { Long lived } \\
\text { timber } \\
\text { C storage } \\
\text { (t C/ha) }\end{array}$ & $\begin{array}{c}\text { Heat from } \\
\text { biomass } \\
\text { combus- } \\
\text { tion }\left(\times 10^{9}\right)\end{array}$ & $\begin{array}{c}\text { Carbon } \\
\text { storage } \\
\text { from coal } \\
\text { substitute } \\
\text { (t C/ha) }\end{array}$ & $\begin{array}{c}\text { Total C } \\
\text { stock*** } \\
\text { (t C/ha) }\end{array}$ & $\begin{array}{c}\text { Total C } \\
\text { sequestra- } \\
\text { tion } \\
\text { rate } \\
\text { (t C/ha/yr) }\end{array}$ \\
\hline \multirow[t]{2}{*}{$\begin{array}{l}\text { Block } \\
\text { plantation }\end{array}$} & $\begin{array}{l}\text { Trees }+ \\
\text { wheat straw }\end{array}$ & 154.3 & 18.67 & 2011.38 & 34.29 & 55.43 & 9.24 \\
\hline & $\begin{array}{l}\text { Trees without } \\
\text { wheat straw }\end{array}$ & 125.65 & 18.67 & 1525.68 & 25.63 & 46.77 & 7.79 \\
\hline \multirow[t]{3}{*}{$\begin{array}{l}\text { Boundary } \\
\text { plantation }\end{array}$} & $\begin{array}{l}\text { Trees + } \\
\text { wheat } \\
+ \text { rice straw }\end{array}$ & 101.78 & 4.43 & 1657.44 & 27.84 & 32.70 & 5.45 \\
\hline & $\begin{array}{l}\text { Trees + rice } \\
\text { straw }\end{array}$ & 72.80 & 4.43 & 1135.8 & 19.08 & 23.94 & 3.99 \\
\hline & $\begin{array}{l}\text { Trees without } \\
\text { rice and } \\
\text { wheat straw }\end{array}$ & 30.14 & 4.43 & 367.92 & 6.18 & 11.04 & 1.84 \\
\hline \multirow[t]{2}{*}{ Control } & $\begin{array}{l}\text { Wheat + rice } \\
\text { straw }\end{array}$ & 102.36 & - & 1842.48 & 30.95 & 31.20 & 5.20 \\
\hline & $\begin{array}{l}\text { Rice straw } \\
\text { only }\end{array}$ & 62.7 & - & 1128.6 & 18.96 & 19.21 & 3.20 \\
\hline
\end{tabular}

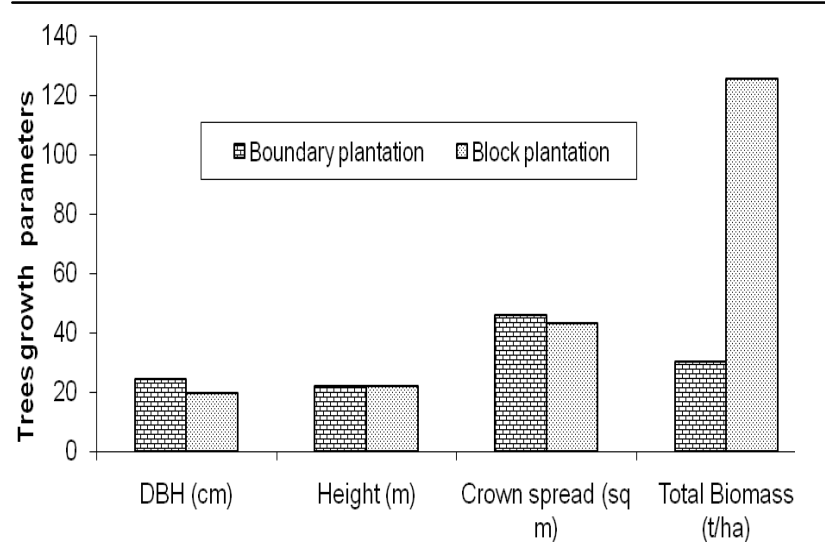

Fig. 1. Trees growth parameters under different planting methods.

(2.11 t/ha). In rice, the controlled plot stored more carbon $(7.32 \mathrm{t} / \mathrm{ha})$ than boundary plantation method $(4.97$ t/ha) but long term crop contribution in carbon storage are negligible (used as food, fodder and fuel), therefore, does not carry much weightage in the ultimate carbon trade business.

The carbon stock in different carbon pools under study indicated that vegetation stock, above-ground biomass followed by below-ground biomass has contributed the maximum towards aggregate carbon pool under agroforestry system. The litter (include roots here) contributed the least towards the aggregate C-stock, which was almost negligible in comparison to other pools. The incremental carbon potential, however, depends upon the productivity of the components (poplar and inter-cultivated crops - wheat/rice). Similar results in poplar with 115 and $64 \mathrm{tC} /$ ha after six years (Gera et

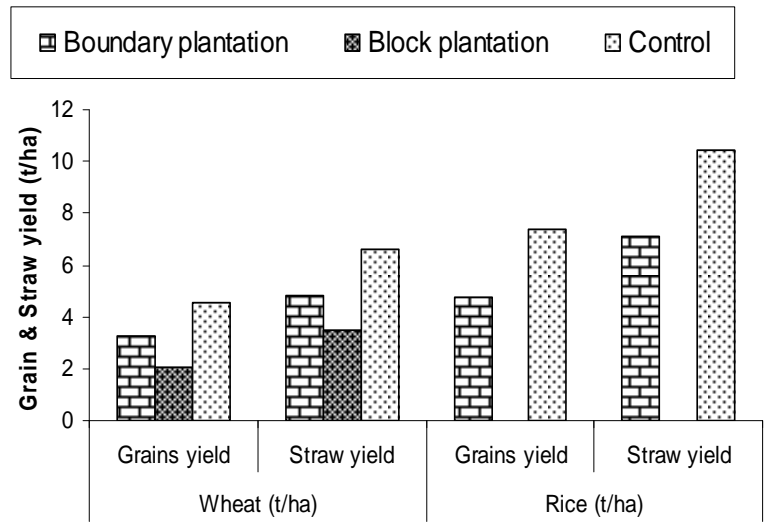

Fig. 2. Grain and straw yield under different planting methods.

al., 2006), 27-32 tC/ha and 16-83 tC/ha after 7 years (under poplar block and bund planting, respectively) and $96.23 \mathrm{tC} / \mathrm{ha}$ after eight years (Singh and Lodhiyal, 2011) in block plantation under irrigated agroecosystem have also been reported earlier.

Carbon sequestration in terms of long term locking/ energy: Arora et al. (2014) estimated biomass based carbon sequestration potential of $173.9 \mathrm{t} / \mathrm{ha}(15.81 \mathrm{t} /$ ha/yr) after eleven years in poplar based system but as we know that less than 50 per cent of the timber is locked in long term wood products and the remaining is used as fuel, therefore, the long lived carbon storages was also calculated in the present study, which was higher with block planting method $(18.67 \mathrm{t} \mathrm{C} / \mathrm{ha})$ as compared to $4.43 \mathrm{t} \mathrm{C/ha}$ in bund plating (Table 1). Since the remaining biomass is used as fuel, which replaces fossil fuel, therefore, the biomass energy was 


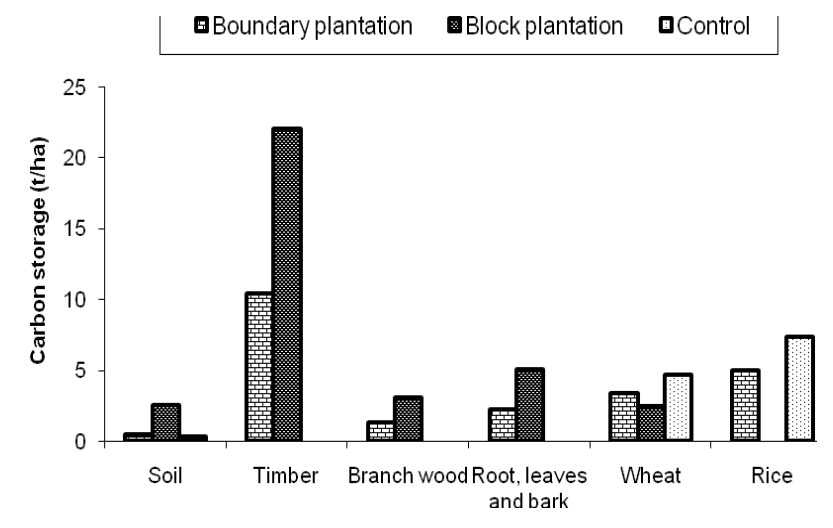

Fig. 3. Estimated carbon storage under different planting methods.

converted to carbon substitute for fossil fuel. The heat from biomass combustion and carbon storage from coal substituted of timber was also higher in the block plantation as compared with boundary plantation. On system basis, boundary plantation includes the poplar, wheat and paddy biomass, whereas, only poplar and wheat biomass in block plantation. The wheat biomass is used as animal fodder in Indian condition but the paddy straw is used as fuel (used as fodder only in scarcity). The heat from biomass combustion and carbon storage from coal substitute and total carbon sequestration was also more in block and boundary plantation than rice-wheat rotation. It is important to notice that the carbon storage from coal substitute was almost similar in boundary system and traditional crop rotation because the contribution of rice straw was substantial, however, the contribution of poplar in block plantation is additional advantage where the long-term timber carbon locking is appreciably high thus reflecting overall advantage (Table 1). The carbon sequestration potential in block plantation with crop components was estimated $9.24 \mathrm{t} / \mathrm{ha} / \mathrm{yr}$ in comparison to 5.54 $\mathrm{t} / \mathrm{ha} / \mathrm{yr}$ in boundary plantation system but higher than traditional crop rotation i.e., $5.20 \mathrm{t} / \mathrm{ha} / \mathrm{yr}$ (provided straw is used as fuel than fodder). Four time higher carbon sequestration potential in poplar-wheat block plantation than boundary plantation system have also been reported (Yadava, 2010) but Kanime et al. (2013) recorded much lower values while converting it in energy values i.e., 2.75 and $0.43 \mathrm{t} / \mathrm{ha} / \mathrm{yr}$ in block and boundary poplar based system. Though these are preliminary estimates and farmers have yet not realized the expected monetary benefits because of limitations attached with the carbon trading schemes.

Economics in poplar based system: Poplar has been accepted and adopted by the farmers on agricultural landscape in irrigated agro-ecosystem due to its high economics than traditionally followed rice-wheat rotation. Farmers with large landholdings prefer to raise poplar in blocks whereas, small farmers raise the trees on bunds only to secure regular livelihood. Higher benefit cost ratio in block plantation (3.30) and bund plantation (1.90) was mainly due to higher rates of poplar timber and higher productivity of the intercropping systems than rice-wheat rotation (1.61). Benefit cost ratio of more than three in poplar based system have also been recorded in earlier studies (Singh and Dhaliwal, 2005; Dwivedi et al., 2007). In addition, poplar cultivation has generated direct as well as indirect employment opportunities (on-farm, transportation, marketing, industry, etc.). The environmental benefits of the plantations can enhance the economic benefit through carbon trading, which have not been accounted due to present uncertain trading of temporary carbon credits. However, Gera et al., (2006) projected that Rs 1038/- to Rs 1857/- (USD 19 and 34, respectively) for bund and block poplar plantation on per hectare per year basis, respectively can be realized in carbon market in addition to the usual income by the farmers from timber sale.

\section{Conclusion}

The focus of sustainable agriculture with enhanced economics has increased interest in tree-crop interface in general and poplar based agroforestry in particular in irrigated agro-ecosystem. The higher productivity of the intercropping system was recorded in the present study with enhanced economics and carbon sequestration potential. Block plantations had more productivity resulting in higher benefit cost ratio in comparison to boundary plantation and traditional rice-wheat crop rotation. The system though with favourable policy initiative can benefit the farmers to harness additional benefits from the carbon market in addition to the present usual timber trade. Energy shift form nonrenewable to renewable (fossil to biomass based) will help in ameliorating the deteriorating environment and accounting long term biomass carbon credits in energy instead of temporary credits through locking biomass in timber products.

\section{ACKNOWLEDGEMENT}

Authors are thankful to Indian Council of Agricultural Research, New Delhi (India) for financial support of Rs. Forty one lakhs to conduct the present investigations.

\section{REFERENCES}

Arora, G., Chaturvedi, S., Kaushal, R., Nain, A., Tewari, S. and Alam, N.M. (2014). Growth, biomass, carbon stocks, and sequestration in age series of Populus deltoides plantations in Tarai region of central Himalaya. Turkish Journal of Agriculture and Forestry, 38: 550560.

Benbi, D.K., Brar, K., Toor, A.S., Singh, P. and Singh, H. (2012). Soil carbon pools under poplar-based agroforestry, rice-wheat, and maize-wheat cropping systems in semi-arid India. Nutrient Cycling and Agroecosystem, 92: 92-107.

Blake, G.R. and Hartage, K.H. (1986). Methods of Soil Analysis (Ed. A. Klute). Part I, $2^{\text {nd }}$ edition, Monograph 9, ASA and SSSA, Madison, WI, pp. 363-375. 
Chandra, J.P. (2011). Development of poplar based agroforestry system. Indian Journal of Ecology, 38: 51-60.

Chauhan, S.K., Sharma, S.C., Chauhan, R. Gupta, N. and Ritu (2010a). Accounting poplar and wheat productivity for carbon sequestration agri-silvicultural system. Ind. For., 136(9): 1174-1182.

Chauhan, S.K., Sharma, S.C., Beri, V., Ritu, Yadav, S. and Gupta, N. (2010b). Yield and carbon sequestration potential of wheat (Triticum aestivum)-poplar (Populus deltoides) based agri-silvicultural system. Indian Journal of Agricultural Sciences, 80: 129-135.

Chauhan, S.K., Gupta,N., Walia, R., Yadav, S., Chauhan, R. and Mangat, P.S. (2011). Biomass and carbon sequestration potential of poplar-wheat inter-cropping system in irrigated agro-ecosystem in India. J. Agri. Sci. \& Tech. A,1(4):575-586.

Chauhan, S.K., Sharma, R., Sharma, S.C., Gupta, N. and Ritu (2012). Evaluation of poplar (Populus deltoides Bartr. ex Marsh.) boundary plantation based agrisilvicultural system for wheat-paddy yield and carbon storage. International Journal of Agriculture and Forestry, 2(5): 239-246.

Coleman, M.D., Isebrands, J.G., Tolsted, D.N. and Tolbert, V.R. (2004). Comparing soil carbon of short rotation poplar plantations with agricultural crops and woodlots in north central United States. Environmental Management, 33: 299-308.

Dhillon, R.S., Wuehlisch, G. and Ajit (2011). Global warming and mitigation through forestry and agroforestry. Indian Journal of Agroforestry, 13: $1-9$.

Dwivedi, R.P., Kareemulla, K., Singh, R., Rizvi, R.H. and Chauhan, J. (2007). Socio-economic analysis of agroforestry system in western Uttar Pradesh. Ind. Res. J. Ext. Edu., 7:18-22.

Gera, M., Mohan, G., Bisht, N.S. and Gera, N. (2006). Carbon sequestration potential under agroforestry in Roopnagar District of Punjab. Indian Forester, 132: 543-555.

Gera, M., Mohan, G., Bisht, N.S. and Gera, N. (2011). Carbon sequestration potential of agroforestry under CDM in Punjab State of India. Indian Journal of Forestry, 34: 1-10.

Gupta, N., Kukal, S.S., Bawa, S.S. and Dhaliwal, G.S. (2009). Soil organic carbon and aggregation under poplar based agroforestry system in relation to tree age and soil type. Agroforestry Systems, 76: 27-35.

Gupta, N., Kukal, S.S. and Singh, P. (2006). Soil erodibility in relation to poplar based agro-forestry system in North Western India. International Journal Agricultural Biology, 8(6): 859-861.

Jose, S. and Bardhan, S. (2012). Agroforestry for biomass production and carbon sequestration: an overview. Agroforestry Systems, 86: 105-111.

Khan, I.A. and Chaturvedi, O.P. (2007). Agroforestry and carbon sequestration: global scenario. Journal of Tropical Forestry, 23: 1-15.

Kanime, N., Kaushal, R., Tewari, S.K., Raverkar, K.P., Chaturvedi, S. and Chaturvedi, O.P. (2013). Biomass production and carbon sequestration in different tree based systems of central Himalaan Tarai region. Forests, Trees and Livelihoods, 22(1): 38-50.

Koul, D.N. and Panwar, P. (2008). Prioritizing landuse management options for carbon sequestration potential.
Current Science, 95(5): 658-663.

Nair, P.K.R., Kumar, B.M. and Nair, V.D. (2009). Agroforestry as a strategy for carbon sequestration. Journal of Plant Nutrition and Soil Science, 172: 10-23.

Nair, P.K.R., Nair, V.D., Kumar, B.M. and Showalter, J.M. (2010). Carbon sequestration in agroforestry systems. Advances in Agronomy, 108: 237-307.

Newman, S.M. (1997). Poplar agroforestry in India. Forest Ecology and Management, 90:13- 17.

Paul, K.I., Polglase, P.J., Nyakuengama, J.G. and Khanna, P.K. (2002). Change in soil carbon following afforestation. Forest Ecology and Management, 168:241-257.

Panse, V.G. and Sukhatme, P.V. (1978). Statistical methods for agricultural workers. ICAR, New Delhi, pp 347.

Pinho, R.C., Miller, R.P. and Alfaia, S.S. (2012). Agroforestry and the improvement of soil fertility: A view from Amazonia. Applied and Environmental Soil Science, Article ID 616383, 11 pages. http:// dx.doi.org/10.1155/2012/616383

Prasad, R. and Nagrajan, S. (2004). Rice-wheat cropping system-food security and sustainability. Current Science. 87: 1334-1335.

Ramesh, T., Manjaiah, K.M., Tomar, J.M.S. and Ngachan, S.V. (2013). Effect of multiputpose tree species on soil fertility and $\mathrm{CO} 2$ efflux under hilly ecosystems of Northesat India. Agroforestry Systems, 87:13771388.

Regmi, A.P., Ladha, J.K., Pathak, H., Pasqui, E., Bueno, C., Dawe, D., Hobbs, P.R., Joshy, D., Maskey, S.L., Pandey, S.P. (2002). Yield and soil fertility trends in 20 year rice-rice-wheat experiment in Nepal. Soil Science Society of America Journal, 66: 857-867.

Rizvi, R.H., Dhyani, S.K., Yadav, R.S. and Singh, R. (2011). Biomass production and carbon stock of poplar agroforestry systems in Yamunanagar and Saharanpur districts of northwestern India. Current Science, 100: 736-742.

Rytter, R.M. (2012). The potential of willow and poplar plantation as carbon sinks in Sweden. Biomass and Bioenergy, 36: 86-95.

Saha, R.and Jha, P. 2012. Carbon sequestration potentials of agroforestry systems under climate change scenariobrief review with special emphasis on north-eastern hill regions. Journal of Agricultural Physics, 12(2): 100106.

Sanchez, F.G., Carter, E.A. and Klepac, J.F. (2003). Enhancing the soil organic pool through biomass incorporation. Biomass and Bioenergy, 24: 337-349.

Sauer, T.J., Cambardella, C.A. and Brandle, J.R. (2007). Soil carbon and tree litter dynamics in a red cedar scotch pine shelterbelt. Agroforestry Systems, 71: 163174.

Schoeneberger, M.M. (2009). Agroforestry: working trees for sequestering carbon on agroforestry lands. Agroforestry Systems, 75: 27-37.

Senapati, N., Ghosh, S., Daniel, H. and Benbi, D.K. (2010). Impact of soil amendments on organic carbon pools under a rice-wheat cropping system. $19^{\text {th }}$ World Congress of Soil Science, Soil Solutions for a Changing World (1-6 October, 2010), Brisbane, Austarlia, pp. 123 $-126$.

Sharma, N.K., Samra, J.S. and Singh, H.P. (2001). Influence of boundary plantation of poplar (Populus del- 
toides M.) on soil-water use and water use efficiency of wheat. Agricultural Water Management, 51:173-185.

Sharma, S.C., Dogra, A.S., Upadhayay, A. and Chahal, G.S. (2007). Carbon stock and productivity assessment of Populus deltoides Bartr. ex Marsh in Punjab. Indian Forester, 133: 8-16.

Singh, P. and Lodhiyal, L.S. (2009). Biomass and carbon allocation in 8 year old poplar (Populus deltoides Marsh) plantation in Tarai agroforestry systems of central Himalaya, India. New York Sci. J., 2: 49-53.

Singh, S. and Dhaliwal, H.S. (2005). An economic analysis of poplar based agroforestry systems in Punjab, India. Indian Journal of Forestry, 28: 381-388.

Singh, G. (2005). Carbon sequestration under an agrisilvicultural system in the arid region. Indian Forester, 131:543-552.

Singh, G. and Rathod, T.R. (2002). Plant growth, biomass production and soil water dynamics in a shifting dune of Indian desert. Forest Ecology and Management, 171: 309-320.

Singh, B. and Sharma, K.N. (2007). Tree growth and nutrient status of soil in a poplar (Populus deltoides Bartr.) based agroforestry system in Punjab, India.
Agroforestry Systems, 70: 25-34.

Schultz, R.C., Isenhart, T.M., Simpkios, W.W. and Colletti, J.P. (2004). Riparian forest buffers in agroecosystemlessons learned from the Bear Creek watershed, central Iowa, USA. Agroforestry Systems, 61: 35-50.

Takimoto, A., Nair, V.D. and Nair, P.K.R. (2009). Contribution of trees to soil carbon sequestration under agroforestry systems in the west African Sahel. Agroforestry Systems, 76:11-25.

Wang, X. and Feng, Z. (1995). Atmospheric carbon sequestration through agroforestry in China. Energy, 20: 11721.

Wani, N.R. and Malik, T.H. (2014). Role of poplars in agroforestry systems in India. New York Science Journal, 7 (2): 50-56.

Yadav, R.S., Yadav, B.L., Chhipa, B.R., Dhyana, S.K. and Munna Ram(2011). Soil biological properties under different tree based traditional agroforestry systems in a semi arid region of Rajasthan, India. Agroforestry Systems, 81:195-202.

Yadava, A.K. (2010). Carbon sequestration: unexploited environmental benefits of Tarai agroforestry systems. Report and Opinion, 2: 35-41. 